\title{
EUROPEAN BANK FOR RECONSTRUCTION AND DEVELOPMENT (EBRD)
}

History. The European Bank for Reconstruction and Development was established in 1991 when communism was collapsing in central and eastern Europe and exSoviet countries needed support to nurture a new private sector in a democratic environment.

Activities. The EBRD is the largest single investor in the region and mobilizes significant foreign direct investment beyond its own financing. It is owned by 60 countries and two intergovernmental institutions. But despite its public sector shareholders, it invests mainly in private enterprises, usually together with commercial partners. Today the EBRD uses the tools of investment to help build market economies and democracies in 27 countries from Central Europe to Central Asia.

It provides project financing for banks, industries and businesses, for both new ventures and investments in existing companies. It also works with publicly-owned companies, to support privatization, restructuring of state-owned firms and improvement of municipal services. The EBRD uses its close relationship with governments in the region to promote policies that will bolster the business environment.

The mandate of the EBRD stipulates that it must only work in countries that are committed to democratic principles. Respect for the environment is part of the strong corporate governance attached to all EBRD investments.

Organization. All the powers of the EBRD are vested in a Board of Governors, to which each member appoints a governor, generally the minister of finance or an equivalent. The Board of Governors delegates powers to the Board of Directors, which is responsible for the direction of the EBRD's general operations and policies. The President is elected by the Board of Governors and is the legal representative of the EBRD. The President conducts the current business of the Bank under the guidance of the Board of Directors.

Headquarters: 1 Exchange Square, London EC2A 2JN, UK.

Website: http://www.ebrd.com

President: Jean Lemierre (France).

Secretary-General (acting): Nigel Carter (UK).

\section{EUROPEAN FREE TRADE ASSOCIATION (EFTA)}

History and Membership. The Stockholm Convention establishing the Association entered into force on 3 May 1960. Founder members were Austria, Denmark, Norway, Portugal, Sweden, Switzerland and the UK. With the accession of Austria, Denmark, Finland, Portugal, Sweden and the UK to the EU, EFTA was reduced to four member countries: Iceland, Liechtenstein, Norway and Switzerland. In June 2001 the Vaduz Convention was signed. It liberalizes trade further among the four EFTA States in order to reflect the Swiss-EU bilateral agreements.

Activities. Free trade in industrial goods among EFTA members was achieved by 1966. Co-operation with the EU began in 1972 with the signing of free trade agreements and culminated in the establishment of a European Economic Area $(E E A)$, encompassing the free movement of goods, services, capital and labour throughout EFTA and the EU member countries. The Agreement was signed by all members of the EU and EFTA on 2 May 1992, but was rejected by Switzerland in a referendum on 6 Dec. 1992. The agreement came into force on 1 Jan. 1994.

The main provisions of the EEA Agreement are: free movement of products within the EEA from 1993 (with special arrangements to cover food, energy, coal and steel); EFTA to assume EU rules on company law, consumer protection, 